\title{
Association between methylenetetrahydrofolate reductase gene rs1801131 A/C polymorphism and urinary tumors' susceptibility
}

\author{
Shuaili $\mathrm{Xu}^{1}$ and Li ZuO ${ }^{2^{*}}$
}

\begin{abstract}
Background: The methylenetetrahydrofolate reductase (MTHFR) rs1801131 A/C variant results in a decrease in MTHFR enzymatic activity, which may play an important role in folate metabolism and is also an important source of DNA methylation and DNA synthesis. Several case-control studies have been conducted to assess the association of MTHFR rs 1801131 polymorphism with the risk of urinary cancers, yet with conflicting conclusions. To derive a more precise estimation of above relationship, the association between the MTHFR rs1801131 A/C polymorphism and the risk of urinary cancer was performed.
\end{abstract}

Methods: A total of 28 case-control studies was identified. The odds ratios (OR) with 95\% confidence intervals (CI) was calculated to assess.

Results: On one hand, we found that the MTHFR rs1801131 A/C polymorphism was associated with increased whole urinary cancers' risk (for example CA vs. $A A: O R=1.12 .95 \% \mathrm{Cl}=1.01-1.24$ ). On the other hand, we found that the MTHFR rs1801131 A/C polymorphism might increase bladder cancer risk both in Asian (C-allele vs. A-allele: $\mathrm{OR}=1.35 .95 \% \mathrm{Cl}=1.15-1.60$ ) and African populations (CA vs. $\mathrm{AA}: \mathrm{OR}=1.63 .95 \% \mathrm{Cl}=1.17-2.25$ ).

Conclusions: Our current analysis suggested that MTHFR rs1801131 A/C is associated with urinary cancers, especially bladder cancer.

Keywords: MTHFR, rs1801131, Prostate, Bladder, Renal, Polymorphism, Risk

\section{Background}

Previous epidemiological studies have shown an association between low folate intake and an increased urinary cancer risk [1,2], meanwhile, folate deficiency may increase cancer risk through impaired DNA repair synthesis and disruption of DNA methylation, which may participate in cancer development [3, 4]. Methylenetetrahydrofolate reductase (MTHFR) plays a

\footnotetext{
* Correspondence: chenyuhuameta@sina.com

${ }^{2}$ Department of Urology, Changzhou No. 2 People's Hospital Affiliated to Nanjing Medical University, Changzhou 213003, Jiangsu Province, China Full list of author information is available at the end of the article
}

crucial role in the metabolism of folates and converts irreversibly $\quad 5,10$-methylenetetrahydrofolate $\quad(5,10-$ MTHF) to 5-MTHF, which is the predominant circulatory form of folate and donates a metyl group for the re-methylation of homocysteine to methionine. Then, the methionine is metabolized to yield Sadenosylmethionine (SAM), which is the main methyl donor for vital methylation reactions and is required for DNA repair [5, 6]. In summary, this gene could influence cancer development.

A common single nucleotide polymorphism (SNP), $\mathrm{A} 1298 \mathrm{C} / \mathrm{rs} 1801131 \mathrm{~A} / \mathrm{C}$, is located in the coding

C C The Author(s). 2020 Open Access This article is licensed under a Creative Commons Attribution 4.0 International License, which permits use, sharing, adaptation, distribution and reproduction in any medium or format, as long as you give appropriate credit to the original author(s) and the source, provide a link to the Creative Commons licence, and indicate if changes were made. The images or other third party material in this article are included in the article's Creative Commons licence, unless indicated otherwise in a credit line to the material. If material is not included in the article's Creative Commons licence and your intended use is not permitted by statutory regulation or exceeds the permitted use, you will need to obtain permission directly from the copyright holder. To view a copy of this licence, visit http://creativecommons.org/licenses/by/4.0/. The Creative Commons Public Domain Dedication waiver (http://creativecommons.org/publicdomain/zero/1.0/) applies to the data made available in this article, unless otherwise stated in a credit line to the data. 
carboxy-terminal regulatory region domain [7] and lymphocytes from individuals containing 1298CC genotype have been found to have approximately $60 \%$ of wild-type in vitro MTHFR activity [8], which acts as a risk factor in cancer development.

Previous studies have investigated that MTHFR rs1801131 A/C was involved in the development of urinary cancers. However, the results of these studies remain conflicting. With the aim to measure the correlation, we performed this comprehensive metaanalysis by adopting all eligible studies [9-34].

\section{Methods}

The search strategy

We searched the Pubmed database (updated on Sep 10, 2018), using combinations of the keywords: 'polymorphism,' or 'variant' or 'mutation' and 'bladder cancer' or 'prostate cancer' or 'renal' and 'MTHFR' or

Table 1 Study characteristics of all included studies about urinary cancer

\begin{tabular}{|c|c|c|c|c|c|c|c|c|c|c|c|c|c|c|c|}
\hline \multirow[t]{2}{*}{ First author } & \multirow[t]{2}{*}{ Year } & \multirow[t]{2}{*}{ Origin } & \multirow[t]{2}{*}{ Ethnicity } & \multirow[t]{2}{*}{ Design } & \multirow{2}{*}{$\begin{array}{l}\text { Source } \\
\text { of } \\
\text { control }\end{array}$} & \multirow[t]{2}{*}{ Case } & \multirow[t]{2}{*}{ Control } & \multicolumn{3}{|c|}{ Case } & \multicolumn{3}{|c|}{ Control } & \multirow{2}{*}{$\begin{array}{l}\text { HWE } \\
\text { in } \\
\text { control }\end{array}$} & \multirow{2}{*}{$\begin{array}{l}\text { Genotype } \\
\text { method }\end{array}$} \\
\hline & & & & & & & & $\mathrm{CC}$ & $C A$ & $A A$ & $\mathrm{CC}$ & CA & $\mathrm{AA}$ & & \\
\hline \multicolumn{16}{|c|}{ Bladder cancer } \\
\hline Ouerhani & 2007 & Tunisia & African & $\mathrm{HB}$ & & 111 & 131 & 6 & 47 & 58 & 9 & 37 & 85 & 0.55 & PCR-RFLP \\
\hline Rouissi & 2009 & Tunisia & African & $H B$ & & 185 & 191 & 10 & 78 & 97 & 10 & 60 & 121 & 0.478 & PCR-RFLP \\
\hline Cai & 2009 & China & Asian & $\mathrm{HB}$ & & 312 & 325 & 6 & 91 & 215 & 7 & 92 & 226 & 0.504 & PCR-RFLP \\
\hline Izmirli & 2011 & Turkey & Caucasian & $\mathrm{HB}$ & & 47 & 50 & 3 & 25 & 19 & 7 & 29 & 14 & 0.195 & PCR-RFLP \\
\hline Safarinejad & 2011 & Iran & Caucasian & $\mathrm{HB}$ & & 158 & 316 & 25 & 85 & 48 & 23 & 115 & 178 & 0.46 & PCR-RFLP \\
\hline Lin & 2004 & USA & African & PB & & 21 & 21 & 0 & 7 & 14 & 0 & 8 & 13 & 0.281 & PCR-RFLP \\
\hline Wang & 2009 & China & Asian & PB & & 239 & 250 & 3 & 67 & 169 & 4 & 75 & 171 & 0.719 & PCR-RFLP \\
\hline Beebe-Dimmer & 2012 & USA & Caucasian & PB & & 218 & 272 & 14 & 109 & 95 & 34 & 111 & 127 & 0.211 & Taqman \\
\hline Karagas & 2005 & USA & Caucasian & $\mathrm{PB}$ & & 350 & 542 & 31 & 146 & 173 & 55 & 220 & 267 & 0.333 & PCR-RFLP \\
\hline Lin & 2004 & USA & Caucasian & PB & & 410 & 409 & 30 & 188 & 192 & 36 & 184 & 189 & 0.35 & PCR-RFLP \\
\hline Moore & 2007 & Spain & Caucasian & $\mathrm{PB}$ & & 1068 & 1078 & 74 & 457 & 537 & 92 & 429 & 557 & 0.467 & TaqMan \\
\hline Sanyal & 2004 & Germany & Caucasian & PB & & 311 & 245 & 33 & 133 & 145 & 24 & 111 & 110 & 0.6 & PCR-RFLP \\
\hline Lin & 2004 & USA & Mixed & PB & & 17 & 17 & 0 & 4 & 13 & 1 & 5 & 11 & 0.678 & PCR-RFLP \\
\hline Moore & 2004 & USA & Mixed & PB & & 106 & 108 & 9 & 45 & 52 & 8 & 45 & 55 & 0.771 & TaqMan \\
\hline
\end{tabular}

Prostate cancer

$\begin{array}{lllll}\text { Cicek } & 2004 & \text { USA } & \text { Mixed } & \text { PB } \\ \text { Collin } & 2009 & \text { UK } & \text { Caucasian } & \text { PB } \\ \text { Cai } & 2010 & \text { China } & \text { Asian } & \text { HB } \\ \text { Safarinejad } & 2010 & \text { Iran } & \text { Caucasian } & \text { HB } \\ \text { Singal } & 2004 & \text { USA } & \text { Caucasian } & \text { HB } \\ \text { Wu } & 2010 & \text { Taiwan } & \text { Asian } & \text { HB } \\ \text { Marchal } & 2008 & \text { Spain } & \text { Caucasian } & \text { HB } \\ \text { Stevens } & 2008 & \text { USA } & \text { Caucasian } & \text { PB } \\ \text { Guelpen } & 2006 & \text { Sweden } & \text { Caucasian } & \text { PB } \\ \text { Muslumanoglu } & 2009 & \text { Turkey } & \text { Caucasian } & \text { HB } \\ \text { López-Cortés } & 2013 & \text { USA } & \text { Caucasian } & \text { PB }\end{array}$

$\begin{array}{llllllllllll}\text { Healthy } & 439 & 478 & 39 & 205 & 195 & 44 & 201 & 233 & 0.945 & \text { PCR-RFLP } & 8 \\ \text { Healthy } & 1592 & 3035 & 144 & 673 & 775 & 289 & 1339 & 1407 & 0.249 & \text { PCR-RFLP } & 9 \\ \text { BPH } & 217 & 220 & 4 & 63 & 150 & 5 & 71 & 144 & 0.27 & \text { PCR-RFLP } & 6 \\ \text { Healthy } & 174 & 348 & 14 & 70 & 90 & 40 & 150 & 158 & 0.628 & \text { PCR-RFLP } & 7 \\ \text { BPH } & 81 & 42 & 9 & 43 & 29 & 7 & 17 & 18 & 0.396 & \text { PCR-RFLP } & 8 \\ \text { Healthy } & 218 & 436 & 10 & 70 & 138 & 14 & 135 & 287 & 0.697 & \text { PCR-RFLP } & 7 \\ \text { Healthy } & 177 & 209 & 17 & 62 & 98 & 22 & 79 & 108 & 0.193 & \text { TaqMan } & 7 \\ \text { Healthy } & 1104 & 1109 & 105 & 518 & 481 & 125 & 493 & 491 & 0.94 & \text { TaqMan } & 7 \\ \text { Healthy } & 222 & 434 & 27 & 108 & 87 & 55 & 203 & 176 & 0.765 & \text { TaqMan } & 7 \\ \text { BPH } & 91 & 166 & 44 & 16 & 31 & 44 & 45 & 77 & <0.05 & \text { PCR-RFLP } & 6 \\ \text { Healthy } & 104 & 110 & 2 & 2 & 100 & 1 & 1 & 108 & <0.05 & \text { PCR-RFLP } & 9\end{array}$

Renal cell carcinoma

$\begin{array}{lllllllllll}168 & 172 & 19 & 106 & 43 & 8 & 105 & 59 & <0.05 & \text { PCR-RFLP } & 6 \\ 152 & 304 & 28 & 88 & 36 & 35 & 131 & 138 & 0.645 & \text { PCR-RFLP } & 9 \\ 818 & 1087 & 85 & 357 & 376 & 113 & 483 & 491 & 0.718 & \text { PCR-RFLP } & 7\end{array}$




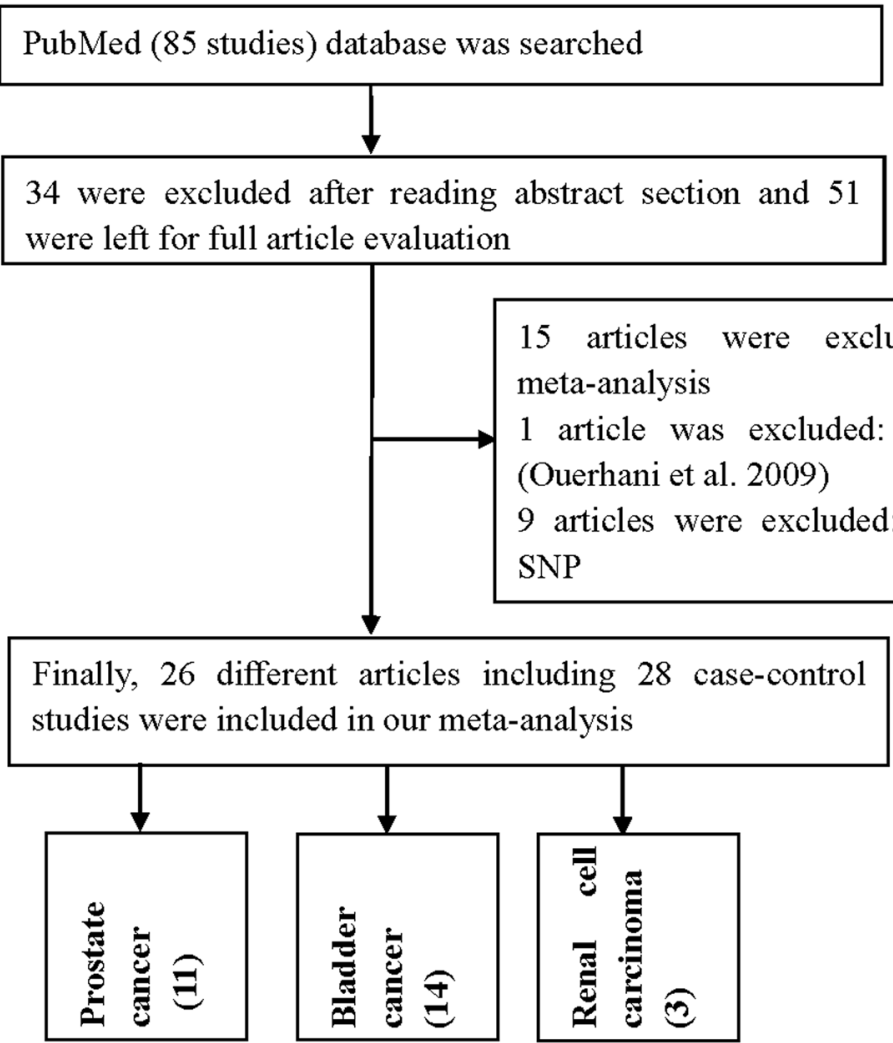

Fig. 1 A flowchart illustrating the search strategy used to identify association studies for MTHFR rs1801131 polymorphism and urinary cancers' risk

\section{rs1801131}

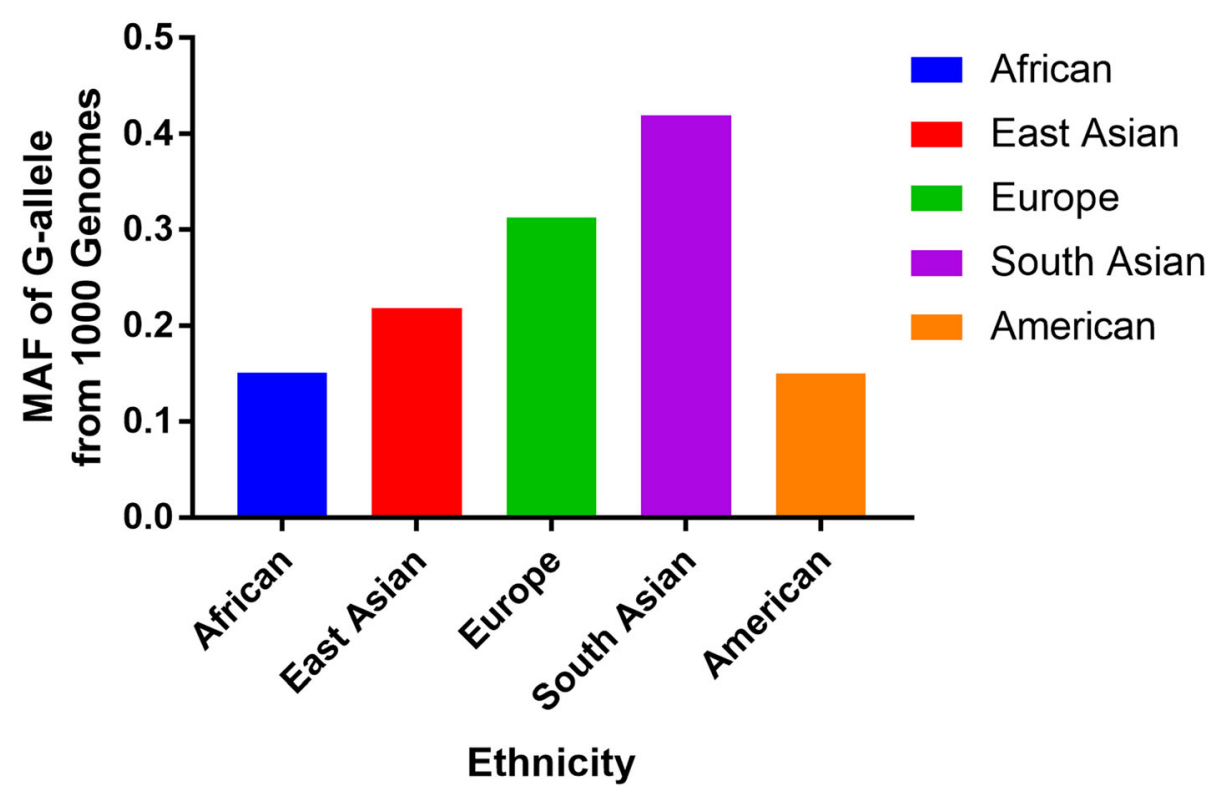

Fig. 2 C-allele frequencies for the MTHFR gene rs1801131 polymorphism among cases/controls stratified by ethnicity. Vertical line, T-allele frequency; Horizontal line, ethnicity type. EAS: East Asian; EUR: European; AFR: African; AMR: American; SAS: South Asian 
'methylenetetrahydrofolate reductase'. All the included studies met the following criteria (1) the association between MTHFR rs1801131 A/C and urinary cancer risk was evaluated; (2) case-control studies were designed; (3) available genotype frequency was collected. The major exclusion criteria were (1) duplications; (2) insufficient reporting data; (3) abstract, commentary, review, editorial article and conference article.

\section{Data extraction}

Two authors carefully extracted data from all eligible publications, independently. The following data were collected from each study: first author's last name, year of publication, race of origin, cancer type, sample size (cases/controls), study design (hospital-based, HB, or population-based, $\mathrm{PB}$ ), source of control for prostate cancer subgroup, Hardy-Weinberg equilibrium (HWE) of controls and genotype method.

\section{Quality score assessment}

The Newcastle-Ottawa Score (NOS) were selected to assess the quality of each study and to assess the various aspects of the methodology used by the observational research, which are relevant to the quality of the study, including the selection of cases, the comparability of groups and the determination of exposure. The total score is from 0 to 9 star. Studies with scores more than 7 are to be as high quality [35].

\section{Statistical analysis}

Odd ratio (OR) with 95\% confidence interval (CI) was used to measure the strength of the association between rs1801131 A/C and urinary cancers. Four

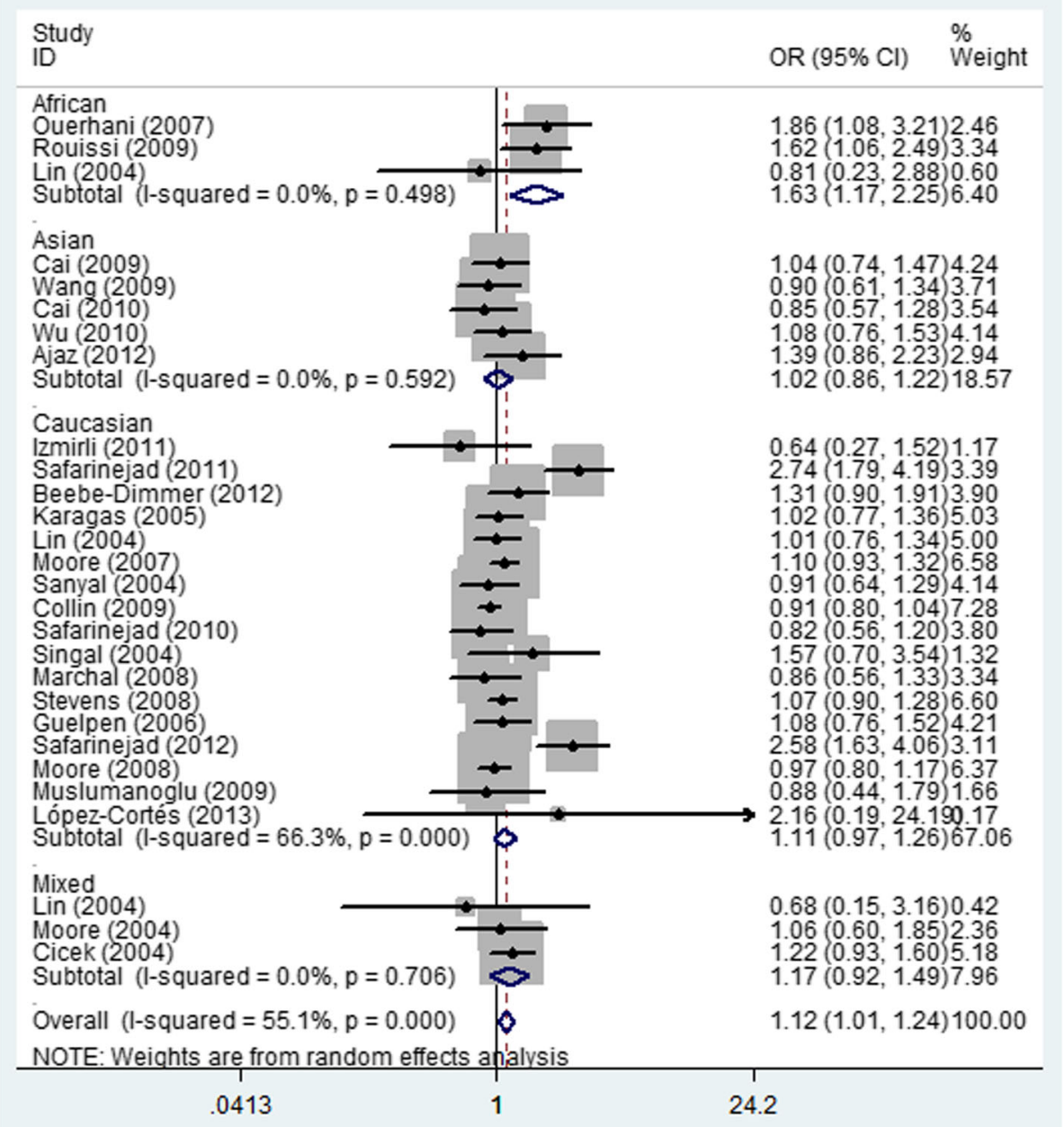

Fig. 3 Forest plot of whole urinary cancers' risk associated with the MTHFR rs1801131 polymorphism (CA vs. AA). The squares and horizontal lines correspond to the study-specific OR and $95 \% \mathrm{Cl}$. The area of the squares reflects the weight (inverse of the variance). The diamond represents the summary OR and $95 \% \mathrm{Cl}$ 


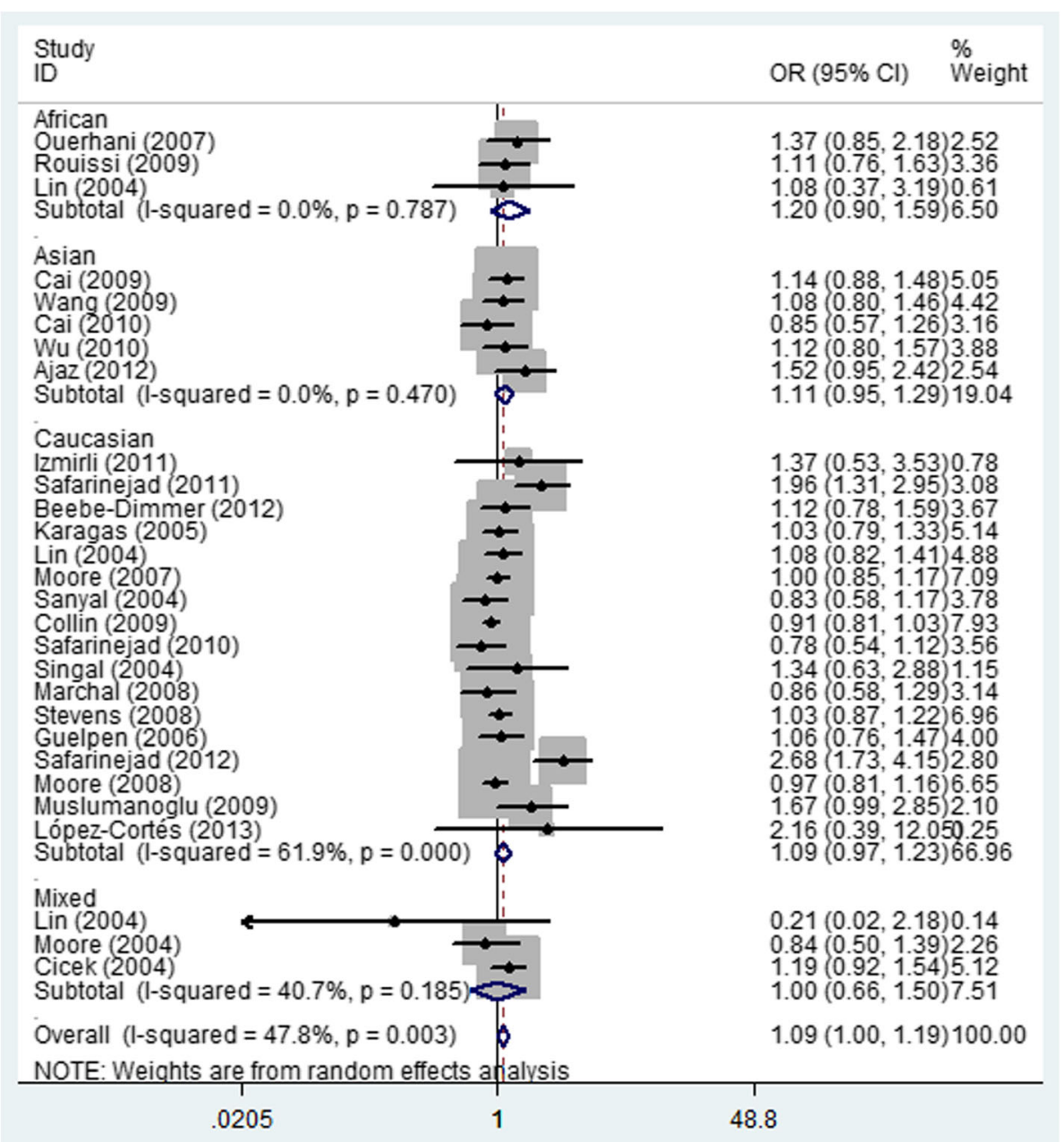

Fig. 4 Forest plot of whole urinary cancers' risk associated with the MTHFR rs1801131 polymorphism (CC + CA vs. AA). The squares and horizontal lines correspond to the study-specific OR and $95 \% \mathrm{Cl}$. The area of the squares reflects the weight (inverse of the variance). The diamond represents the summary OR and $95 \% \mathrm{Cl}$

different genetic models were applied to evaluate above association: allelic contrast (C-allele vs. Aallele), heterozygote comparison (CA vs. AA), dominant genetic model $(\mathrm{CC}+\mathrm{CA}$ vs. $\mathrm{AA})$, and recessive genetic model ( $\mathrm{CC}$ vs. $\mathrm{CA}+\mathrm{AA})$. The ethnic descents were categorized as Caucasian, Asian, African, or Mixed. The control group based on sources was divided as follows: $\mathrm{HB}, \mathrm{PB}$, benign prostatic hyperplasia $(\mathrm{BPH})$, and healthy man.

The statistical significance of the summary OR was determined with the $Z$-test. The heterogeneity was evaluated by both Cochrane $Q$-test $[36,37]$ and $I^{2}$ metric $[38,39]$ ranging from 0 to $100 \%$. When $P$ for the heterogeneity test $\left(P_{h}\right)<0.10$ and $I^{2}>50 \%$ [40], the pooled OR of each study was calculated by using the random-effects model; otherwise, the fixed-effects model was used [41, 42].
Subgroup analysis was performed according to the ethnicity and the source of cases to explore potential heterogeneity. The meta-regression analysis is a technique used to assess heterogeneity between the studies [43]. This statistical approach determines whether there is a significant association between the study period and number of individuals with the pooled OR [43]. The funnel plot asymmetry and publication bias were assessed using Egger's test and Begg's test, respectively [44, 45]. The departure of frequencies of MTHFR rs1801131 A/C from expected values under HWE was assessed in controls by using the Pearson chi-square test. All statistical tests were performed using the Stata software (Version 11.0; StataCorp LP, College Station, TX).

The PolyPhen-2 bioinformatic tool was used to predict the effects of gene SNPs on the translated proteins. In 
Table 2 Total and stratified analysis of MTHFR rs1801131 A/C polymorphism and each urinary cancer variables

\begin{tabular}{|c|c|c|c|c|c|c|}
\hline \multirow[t]{2}{*}{ Variables } & \multirow[t]{2}{*}{$\mathrm{N}$} & \multirow{2}{*}{$\begin{array}{l}\text { Case/ } \\
\text { Control }\end{array}$} & C-allele vs. A-allele & CA vs. AA & $C C$ vs. $C A+A A$ & $C C+C A$ vs. AA \\
\hline & & & $\mathrm{OR}(95 \% \mathrm{Cl}) \boldsymbol{P}_{\mathrm{h}}$ & $\mathrm{OR}(95 \% \mathrm{Cl}) \boldsymbol{P}_{\mathbf{h}}$ & $\mathrm{OR}(95 \% \mathrm{Cl}) \boldsymbol{P}_{\mathrm{h}}$ & $\mathrm{OR}(95 \% \mathrm{Cl}) \boldsymbol{P}_{\mathbf{h}}$ \\
\hline Total & 28 & $9110 / 12105$ & $1.06(0.98-1.15) 0.000$ & $1.12(1.01-1.24) 0.000$ & $1.01(0.87-1.17) 0.021$ & $1.09(1.00-1.19) 0.003$ \\
\hline HWE & 25 & $8747 / 11657$ & $1.03(0.96-1.11) 0.001$ & $1.11(1.00-1.24) 0.000$ & $0.93(0.84-1.02) 0.432$ & $1.06(0.98-1.16) 0.006$ \\
\hline \multicolumn{7}{|c|}{ Prostate cancer } \\
\hline Total & 11 & $4419 / 6587$ & $1.02(0.91-1.14) 0.016$ & $0.99(0.91-1.07) 0.569$ & $1.00(0.81-1.25) 0.062$ & $0.99(0.91-1.07) 0.253$ \\
\hline HWE & 9 & $4224 / 6311$ & $0.96(0.91-1.02) 0.656$ & $0.99(0.91-1.07) 0.423$ & $0.90(0.79-1.04) 0.918$ & $0.97(0.90-1.05) 0.461$ \\
\hline \multicolumn{7}{|l|}{ Ethnicity } \\
\hline Caucasian & 8 & $3545 / 5453$ & $1.02(0.88-1.17) 0.008$ & $0.96(0.88-1.06) 0.622$ & $0.96(0.83-1.10) 0.020$ & $0.96(0.88-1.05) 0.244$ \\
\hline Asian & 2 & $435 / 656$ & $1.02(0.81-1.27) 0.250$ & $0.97(0.75-1.27) 0.392$ & $1.23(0.61-2.48) 0.546$ & $0.99(0.77-1.29) 0.300$ \\
\hline Mixed & 1 & $439 / 478$ & NA & NA & NA & NA \\
\hline \multicolumn{7}{|c|}{ Source of control } \\
\hline $\mathrm{HB}$ & 6 & $958 / 1421$ & $1.05(0.81-1.37) 0.003$ & $0.93(0.78-1.12) 0.701$ & $0.57(0.44-0.75) 0.530$ & $1.09(0.64-1.85) 0.017$ \\
\hline PB & 5 & $3461 / 5166$ & $0.97(0.91-1.04) 0.485$ & $1.00(0.91-1.10) 0.269$ & $1.08(0.85-1.36) 0.004$ & $0.91(0.79-1.06) 0.885$ \\
\hline $\mathrm{BPH}$ & 3 & $389 / 428$ & $1.22(0.70-2.13) 0.004$ & $0.95(0.68-1.31) 0.411$ & $1.22(0.44-3.40) 0.310$ & $1.12(0.84-1.50) 0.116$ \\
\hline Healthy & 8 & $4030 / 6159$ & $0.97(0.91-1.03) 0.454$ & $0.99(0.91-1.08) 0.454$ & $0.91(0.79-1.05) 0.863$ & $0.98(0.90-1.06) 0.39$ \\
\hline \multicolumn{7}{|c|}{ Bladder cancer } \\
\hline Total & 14 & $3553 / 3955$ & $1.04(0.93-1.16) 0.009$ & $1.17(0.99-1.38) 0.005$ & $0.89(0.74-1.06) 0.268$ & $1.07(0.98-1.17) 0.259$ \\
\hline \multicolumn{7}{|l|}{ Ethnicity } \\
\hline Caucasian & 7 & $2512 / 2912$ & $1.01(0.90-1.14) 0.085$ & $1.17(0.92-1.48) 0.001$ & $0.90(0.66-1.23) 0.033$ & $1.09(0.93-1.29) 0.069$ \\
\hline Asian & 2 & $551 / 575$ & $1.35(1.15-1.60) 0.941$ & $0.98(0.76-1.27) 0.599$ & $0.92(0.38-2.25) 0.893$ & $1.11(0.91-1.36) 0.792$ \\
\hline Mixed & 2 & $123 / 125$ & $0.75(0.51-1.09) 0.286$ & $1.00(0.59-1.70) 0.594$ & $1.04(0.41-2.65) 0.469$ & $0.78(0.48-1.27) 0.258$ \\
\hline African & 3 & $317 / 343$ & $0.91(0.72-1.14) 0.627$ & $1.63(1.17-2.25) 0.498$ & $0.88(0.44-1.75) 0.702$ & $1.20(0.90-1.59) 0.787$ \\
\hline \multicolumn{7}{|c|}{ Source of control } \\
\hline $\mathrm{HB}$ & 5 & $813 / 1013$ & $1.16(0.90-1.49) 0.024$ & $1.49(0.96-2.30) 0.002$ & $1.24(0.84-1.84) 0.137$ & $1.29(1.09-1.54) 0.235$ \\
\hline PB & 9 & $2740 / 2942$ & $0.99(0.91-1.07) 0.103$ & $1.05(0.94-1.17) 0.902$ & $0.82(0.67-0.99) 0.788$ & $1.00(0.91-1.11) 0.829$ \\
\hline \multicolumn{7}{|c|}{ Renal cell carcinoma } \\
\hline Total & 3 & $1138 / 1563$ & $1.33(0.90-1.98) 0.000$ & $1.47(0.81-2.68) 0.000$ & $1.50(0.86-2.59) 0.041$ & $1.54(0.82-2.92) 0.000$ \\
\hline HWE & 2 & 970/1391 & $1.32(0.72-2.42) 0.000$ & $1.54(0.59-4.03) 0.000$ & $1.26(0.74-2.14) 0.080$ & $1.58(0.58-4.28) 0.000$ \\
\hline
\end{tabular}

$P h$ value of Q-test for heterogeneity test, NA not available

the PolyPhen-2 analysis, the scores could range from 0 to 1 , where a score of zero meant 'benign' and a score of one meant 'probably damaging'.

\section{Network of gene-interaction of MTHFR gene}

The network of gene-gene interaction for MTHFR gene was utilized through String online server (http:// string-db.org/) [46].

\section{Results}

\section{Study characteristics}

After reviewing the title, abstract, and full text, 51 different papers were included for the final analysis, expect for papers focusing on meta-analyses, reviews, case-only studies, and other gene polymorphisms.
For bladder cancer, Ouerhani et al. published two papers in 2007 and 2009 that contained duplicated data about, so we included the larger numbers from Ouerhani (2007) et al. [24] in our analysis. Then, 15 different articles were review or meta-analysis. Moreover, another 9 papers were focus just only MTHFR C677T (rs1801133) polymorphism. Finally, we identified 26 different papers describing 28 case-control studies (11 case-control studies for prostate cancer, 14 for bladder cancer, and three for renal cell carcinoma, Table 1, Fig. 1) [9-34] to evaluate the association of MTHFR rs1801131 A/C. Study characteristics are shown in Table 1. The distribution of genotypes in the controls was consistent with HWE in all studies, except for three papers. The 


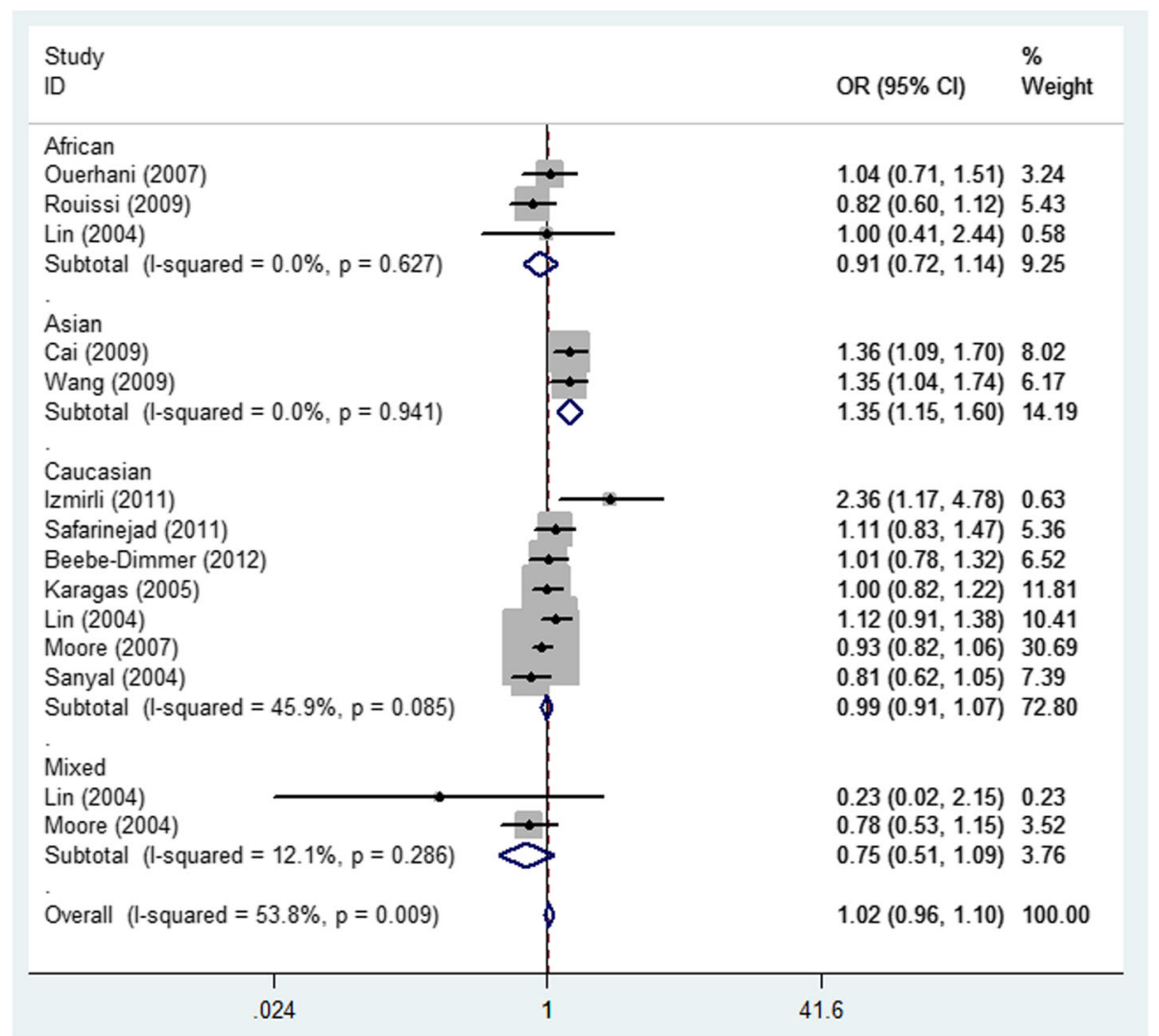

Fig. 5 Forest plot of bladder cancer risk associated with the MTHFR rs 1801131 polymorphism (C-allele vs. A-allele) by ethnicity subgroup. The squares and horizontal lines correspond to the study-specific OR and $95 \% \mathrm{Cl}$. The area of the squares reflects the weight (inverse of the variance). The diamond represents the summary OR and $95 \% \mathrm{Cl}$

average NOS of including studies is 7.571, which means our results is credible and representational. None of the control populations had a history of malignant diseases. Genotyping methods were conducted using polymerase chain reaction and restrictive fragment length polymorphism (PCR-RFLP), and TaqMan technologies. Finally, we checked the Minor Allele Frequency (MAF) reported for the five main worldwide populations in the 1000 Genomes Browser (https:// www.ncbi.nlm.nih.gov/snp/rs1801131\#frequency_tab): East Asian (EAS), 0.219; European (EUR), 0.313; African (AFR), 0.151; American (AMR), 0.15; and South Asian (SAS), 0.42 (Fig. 2). The MAF in our analysis was 0.331 and 0.325 in the case and control group, respectively, both higher than the results in the EAS from1000 Genomes Browser database.

\section{Quantitative synthesis}

\section{Total urinary cancers}

In the total analysis, significant increased relationship was found in both heterozygote comparison $(\mathrm{OR}=1.12$; 95\% CI $=1.01-1.24 ; P=0.387$ for heterogeneity, Fig. 3) and dominant genetic model $(\mathrm{OR}=1.09 ; 95 \% \mathrm{CI}=1.00-$
1.19; $P=0.003$ for heterogeneity, Fig. 4) between MTHFR rs1801131 A/C and urinary cancer risk. At the same time, if we excluded three papers that were not consistent with HWE, also similar association was detected (Table 2).

\section{Prostate cancer}

Overall, there were no significant relationships between MTHFR rs1801131 A/C and prostate cancer risk in any of the available genotype models. Moreover, to avoid publishing bias, two papers that were not consistent with HWE were excluded, so 9 casecontrol studies were left for analysis, and, to our regret, no association was also detected. Finally, based on ethnicity-stratified and source of control subgroup analysis, there remain no significant association were found (Table 2).

\section{Bladder cancer}

Detailed results of the meta-analysis are shown in Table 2. No statistically significant association was detected between MTHFR rs1801131 A/C and bladder cancer risk in the total group or in the all articles 


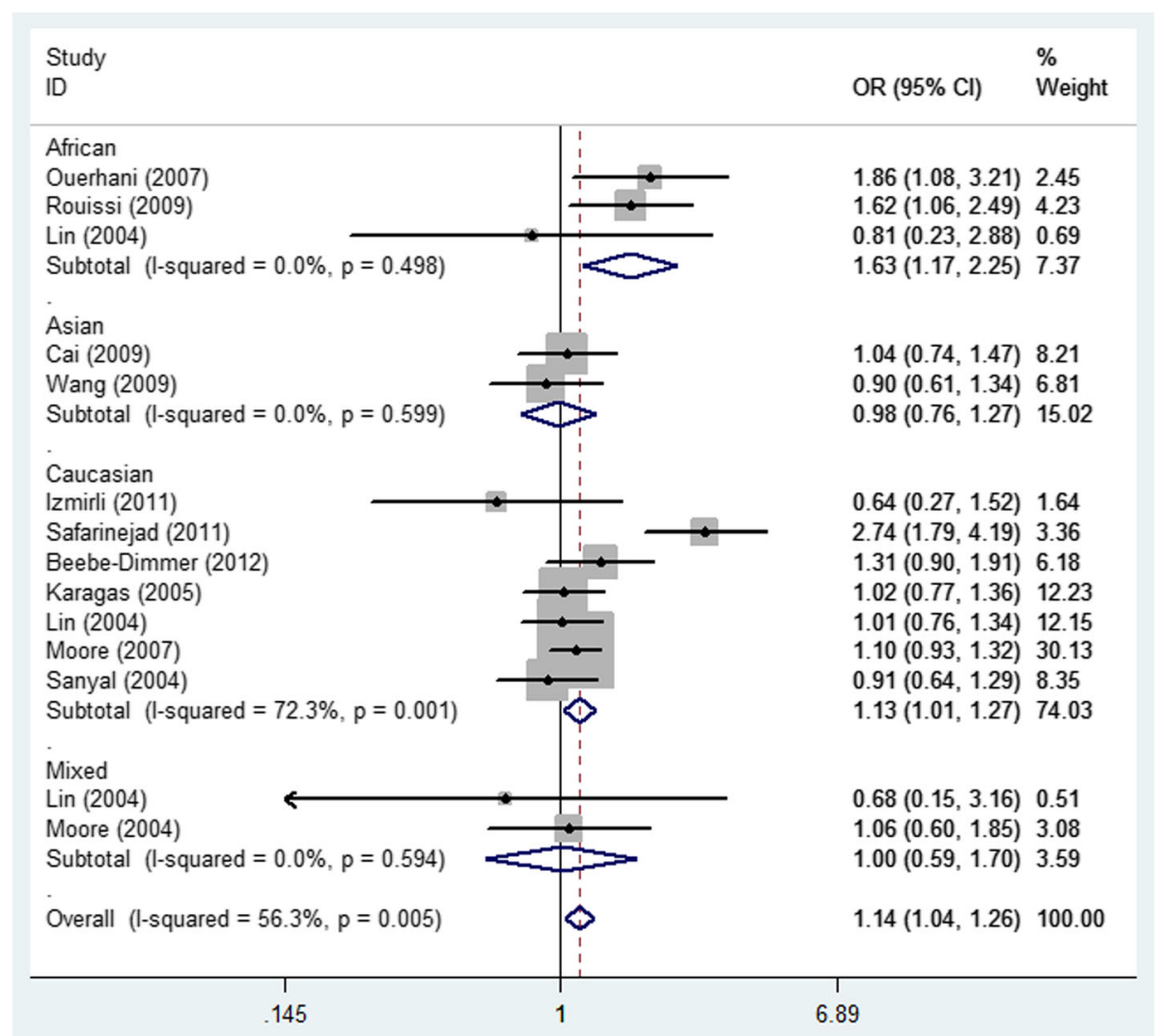

Fig. 6 Forest plot of bladder cancer risk associated with the MTHFR rs1801131 polymorphism (CA vs. AA) by ethnicity subgroup. The squares and horizontal lines correspond to the study-specific OR and $95 \% \mathrm{Cl}$. The area of the squares reflects the weight (inverse of the variance). The diamond represents the summary OR and $95 \% \mathrm{Cl}$

according to HWE. Interestingly, in the ethnicity subgroup analysis, there was a increased risk of bladder cancer in the Asian population (allelic contrast: OR = $1.35,95 \% \mathrm{CI}=1.15-1.60, P_{\text {heterogeneity }}=0.941$, Fig. 5), and African population (heterozygote comparison: $\mathrm{OR}=1.63, \quad 95 \% \mathrm{CI}=1.17-2.25, \quad P_{\text {heterogeneity }}=0.498$, Fig. 6), but not in Caucasians, or Mixed (Table 2). Moreover, in the subgroup analysis in source of control, also increased relationship was detected in dominant genetic model $(\mathrm{OR}=1.29,95 \% \mathrm{CI}=1.09-1.54$, $P_{\text {heterogeneity }}=0.235$, Fig. 7 ).

\section{Renal cell carcinoma}

In the total and only HWE analysis, no increased relationship was found between MTHFR rs1801131 A/C and renal cell carcinoma (Table 2).

\section{Meta-regression}

Considering the subgroup of ethnicity, source of control, and control type as independent variables and the $\log (\mathrm{OR})$ as dependent variable, the random-effect meta-regression results were presented in Fig. 8. To estimate the functional relationship of the $\log$ OR with above three items, the analysis showed only a significant relationship for allele model (C-allele vs. A-allele) for the ethnicity with a regression coefficient of 0.009 in bladder cancer, rather than other subgroups and other urinary cancers, which means the heterogeneity for rs1801131 polymorphism in bladder cancer may be from the subgroup of ethnicity.

\section{Publication bias diagnosis and sensitivity analysis}

Begg's funnel plot and Egger's test were performed to access the publication bias of the literature. The shape of the funnel plot did not reveal obvious asymmetry and the Egger's test suggested the absence of publication bias [for example (CA vs. AA) $(\mathrm{z}=1.61$, $P=0.119$ for Begg's test; $\mathrm{t}=1.01, P=0.314$ for Egger's test, Figs. 9, 10)]. Instead of above, we also deleted each study involved in our meta-analysis to reflect the influence of the individual data-set on the pooled OR, then the corresponding pooled OR was not 


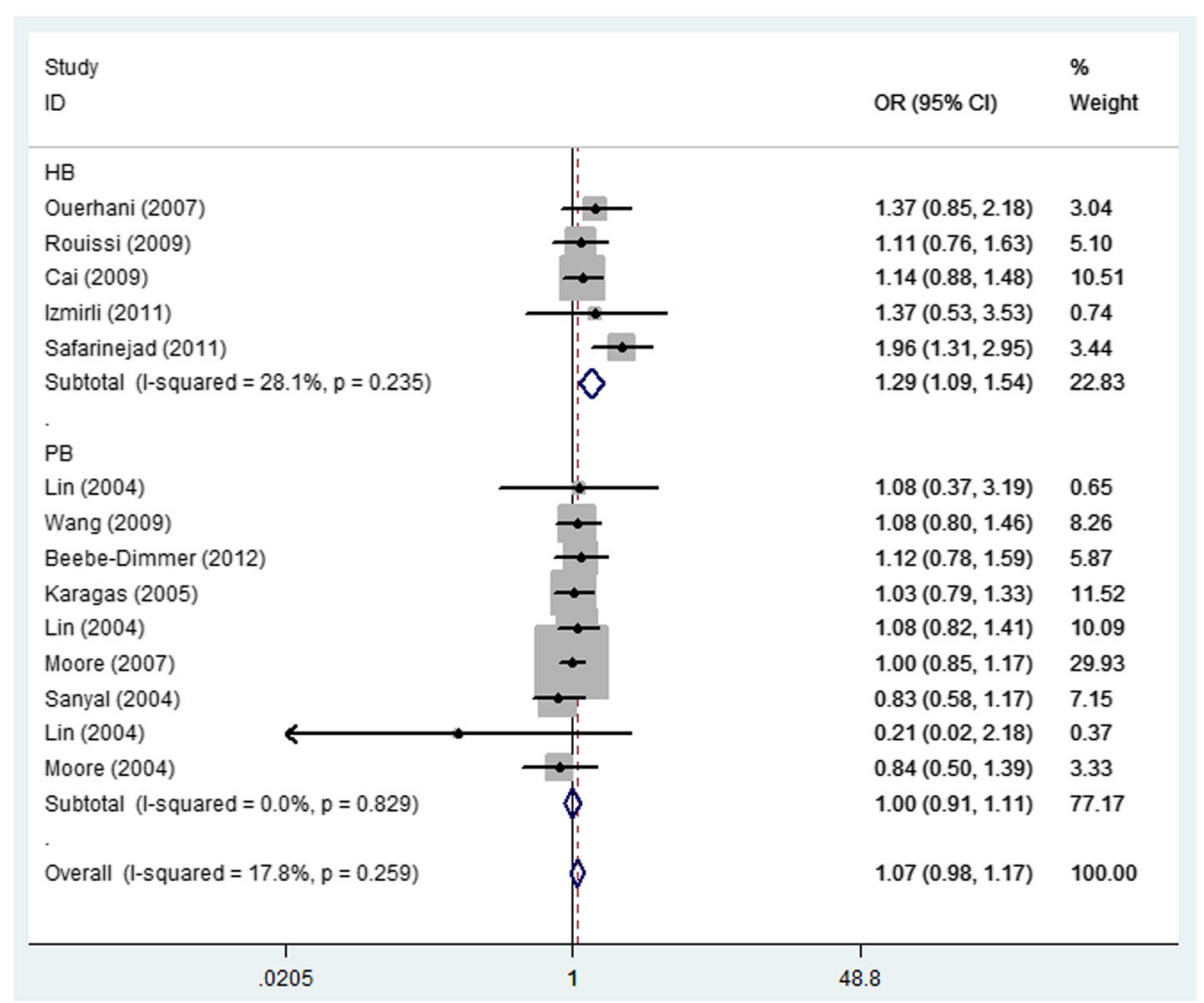

Fig. 7 Forest plot of bladder cancer risk associated with the MTHFR rs1801131 polymorphism (CC + CA vs. AA) by source of control subgroup. The squares and horizontal lines correspond to the study-specific OR and $95 \% \mathrm{CI}$. The area of the squares reflects the weight (inverse of the variance). The diamond represents the summary OR and $95 \% \mathrm{Cl}$

significantly altered, indicating that our results were statistically robust (for example: allelic contrast, Fig. 11).

\section{PolyPhen-2 analysis}

To verify this association, we used the PolyPhen- 2 tool to analyze the features of the rs1801131 mutant. A score of 0.021 was obtained from the analysis, suggesting the possibility of rs1801131 not being a damaging mutation (Fig. 12).

\section{Gene-gene interaction of online analysis}

String online server indicated that MTHFR gene interacts with numerous genes. The network of gene-gene interaction has been illustrated in Fig. 13.

\section{Discussion}

Our study was focused on the MTHFR rs1801131 polymorphism. The mutant C-allele of the MTHFR rs1801131 polymorphism has been reported to reduce the MTHFR enzymatic activity of the wild type A-allele [8], which may increase cancer risk. For example, Safarinejad et al. [27] reported that reduced levels of MTHFR mRNA had an increased association with the risk in men bladder cancer, which may be explained by the hypothesis that reduced MTHFR mRNA level may influence the metabolism of folic acid, then decrease supply of 5-MTHF in serum, along with the increase other forms of folic acid, which leads to affect the synthesis of the pyrimidine and purine, resulting in damaged in DNA synthesis and repair, finally contributes to cancer development.

This is the first meta-analysis to estimate the relationship between MTHFR rs1801131 and urinary cancers' risk, involving approximately 9110 cancer cases and 12,105 controls. Increased associations were found between this polymorphism and urinary cancers. Moreover, in the specific bladder cancer, this polymorphism was associated with increased bladder cancer's susceptibility in Asians and Africans, but not Caucasians, in some different genetic models. The classic five genetic models were applied very popular and credible. If one of five model is significant, this group is considered as positive association. Additional, between different subgroups, such as ethnicity, it is normal that the associations were detected in different genetic models or the same models, because different items were existed among the groups. The polymorphism may act as a risk factor in urinary cancers, especially bladder cancer, possibly through the mechanism described above. 

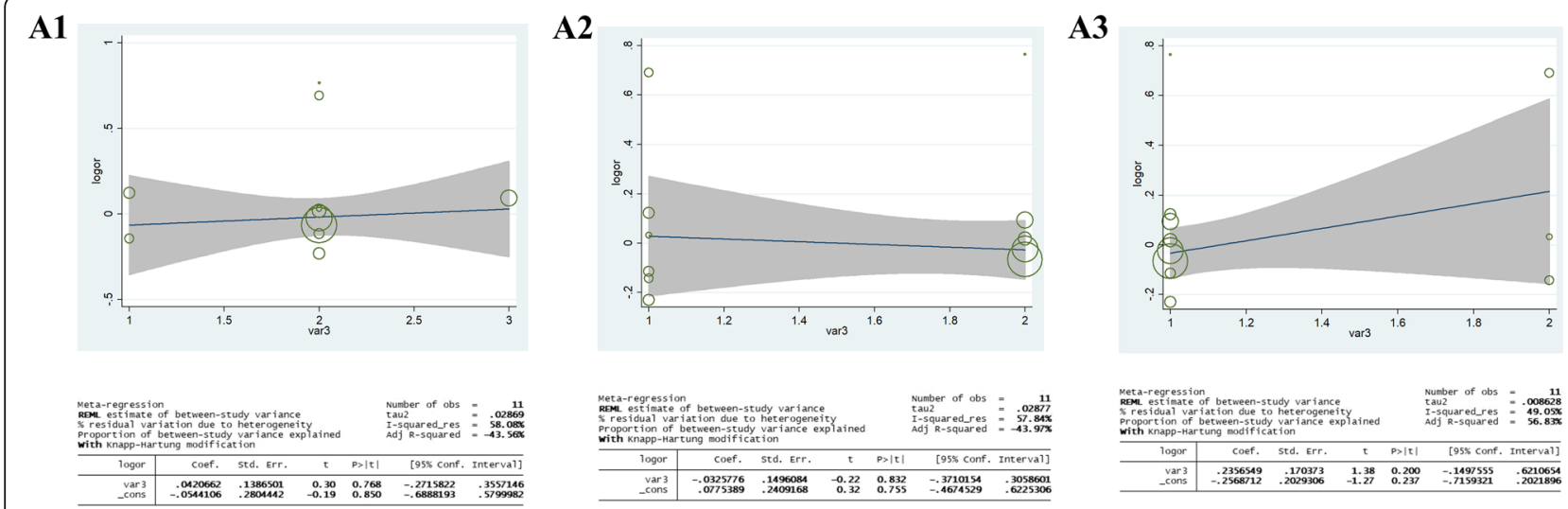

B1
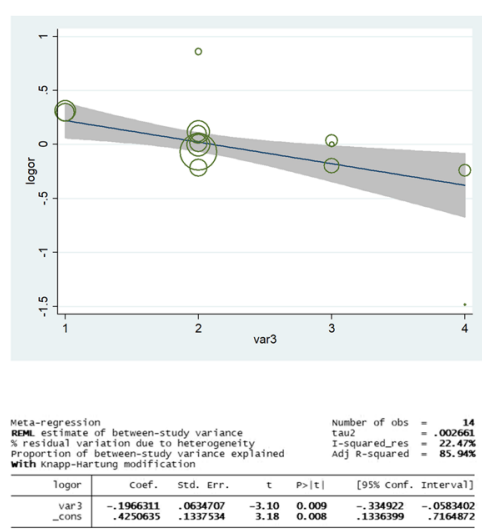

C1
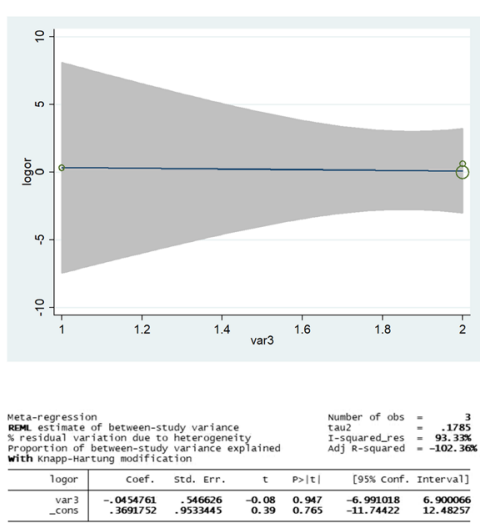

B2
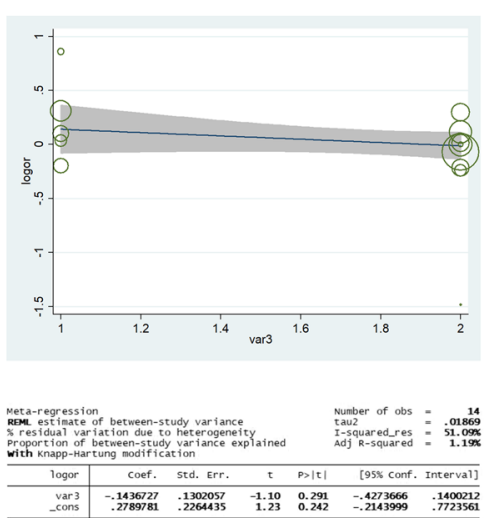

$\mathrm{C} 2$
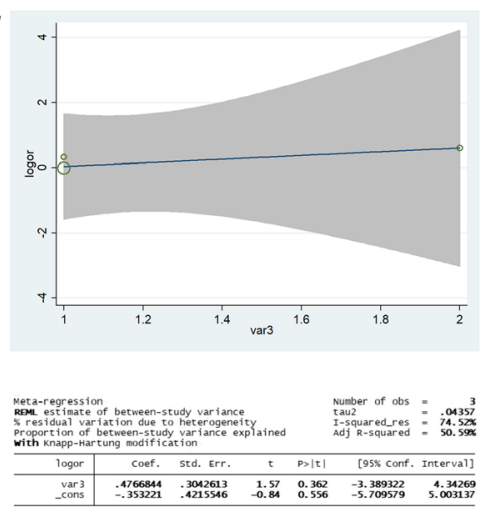

Fig. 8 Random-effect meta-regression of log odds ratio versus ethnicity (A1), source of control (A2), control type (A3), respectively in prostate cancer. Random-effect meta-regression of log odds ratio versus ethnicity (B1), source of control (B2), respectively in bladder cancer. Randomeffect meta-regression of log odds ratio versus ethnicity (C1), source of control (C2), respectively in renal cell carcinoma

Interestingly, previous two meta-analysis reported that another MTHFR rs1801133 (C677T) had a decreased association in whole cancer risk and urinary cancers [47, 48]. Above two different polymorphisms in the same MTHFR gene had the complete opposite function. Following reasons may explain above results. First, different polymorphism sites may have the opposite effect on the expression of its host gene. Second, cancer is a complex disease, and may not be depended entirely on a gene or one kind of polymorphism, moreover, gene-gene or gene-environment factors may play a significant influence on the susceptibility of urinary cancers [49].

In addition, we used the online analysis systemString to predict potential and functional partners 


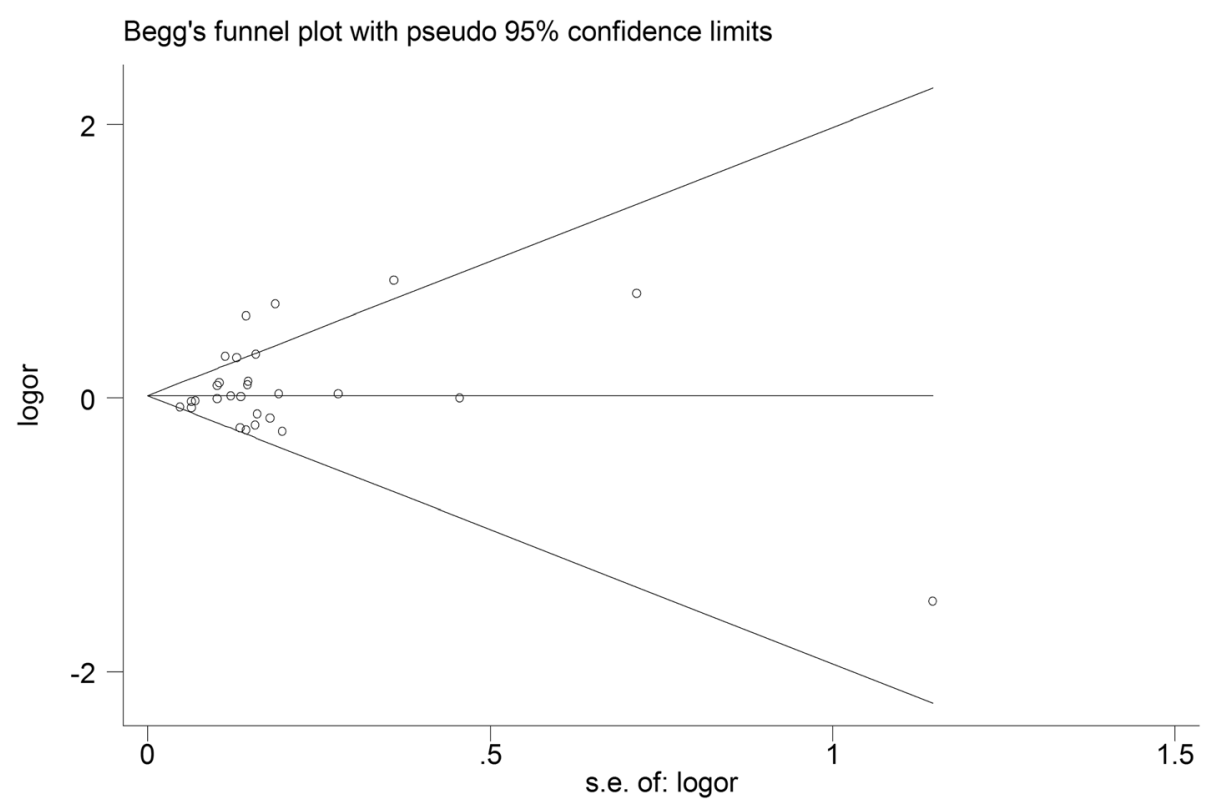

Fig. 9 Begg's funnel plot for publication bias test (CA vs. AA). Each point represents a separate study for the indicated association. Log [OR], natural logarithm of OR. Horizontal line, mean effect size

(Fig. 12). Finally, 10 genes were predicted. The highest score of association was MTR (Score $=0.999$ ), however, MTHFD1L was the last in line (Score= 0.896). Enzymes in one-carbon metabolism genes, such as MTR, MTHFD, TYMS, SHMT, MTHFR can both regulate the metabolism of folate, and low folate levels can induce carcinogenesis [50-53]. First, polymorphisms in MTR gene increase homocysteine in the plasma, resulting in changes to the folate pathway and increasing association of carcinogenesis [54, 55]. Second, MTHFD polymorphisms (G1958A and T401C) had a strong association with total plasma

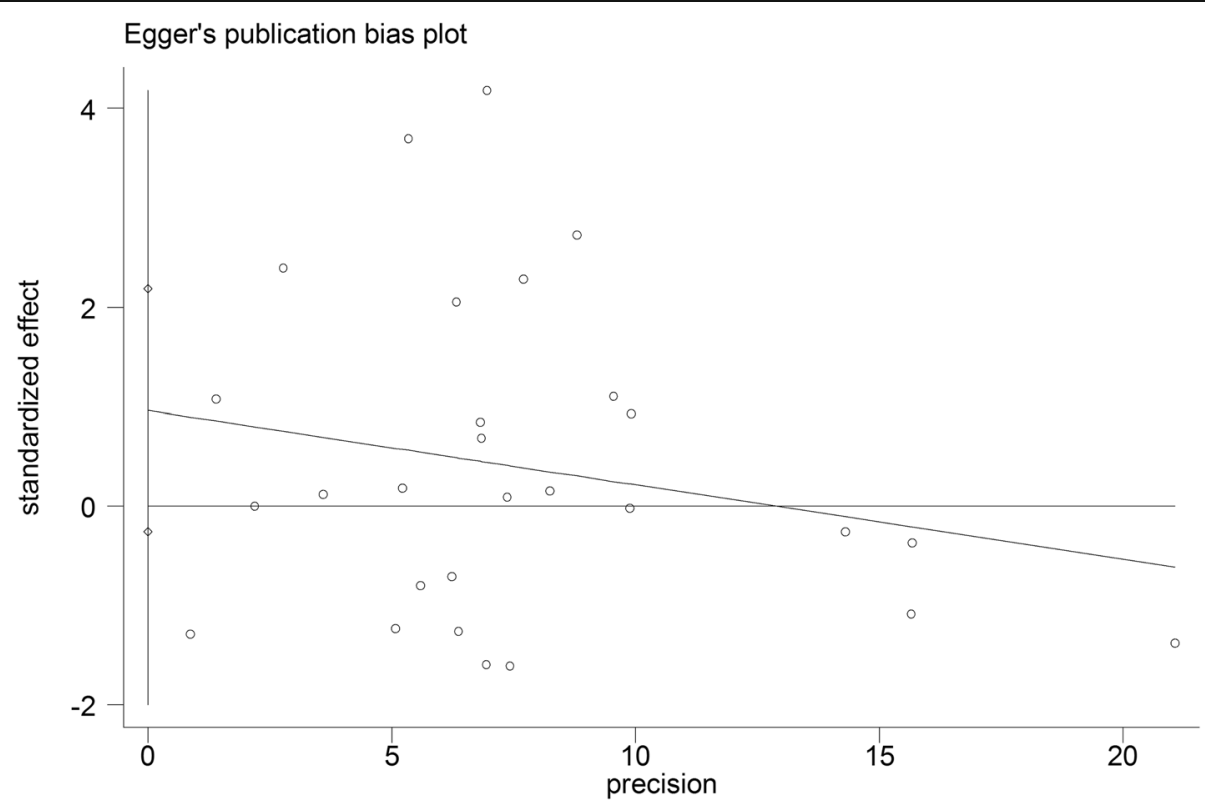

Fig. 10 Egger's publication bias plot (CA vs. AA). Each point represents a separate study for the indicated association. Horizontal line, mean effect size 


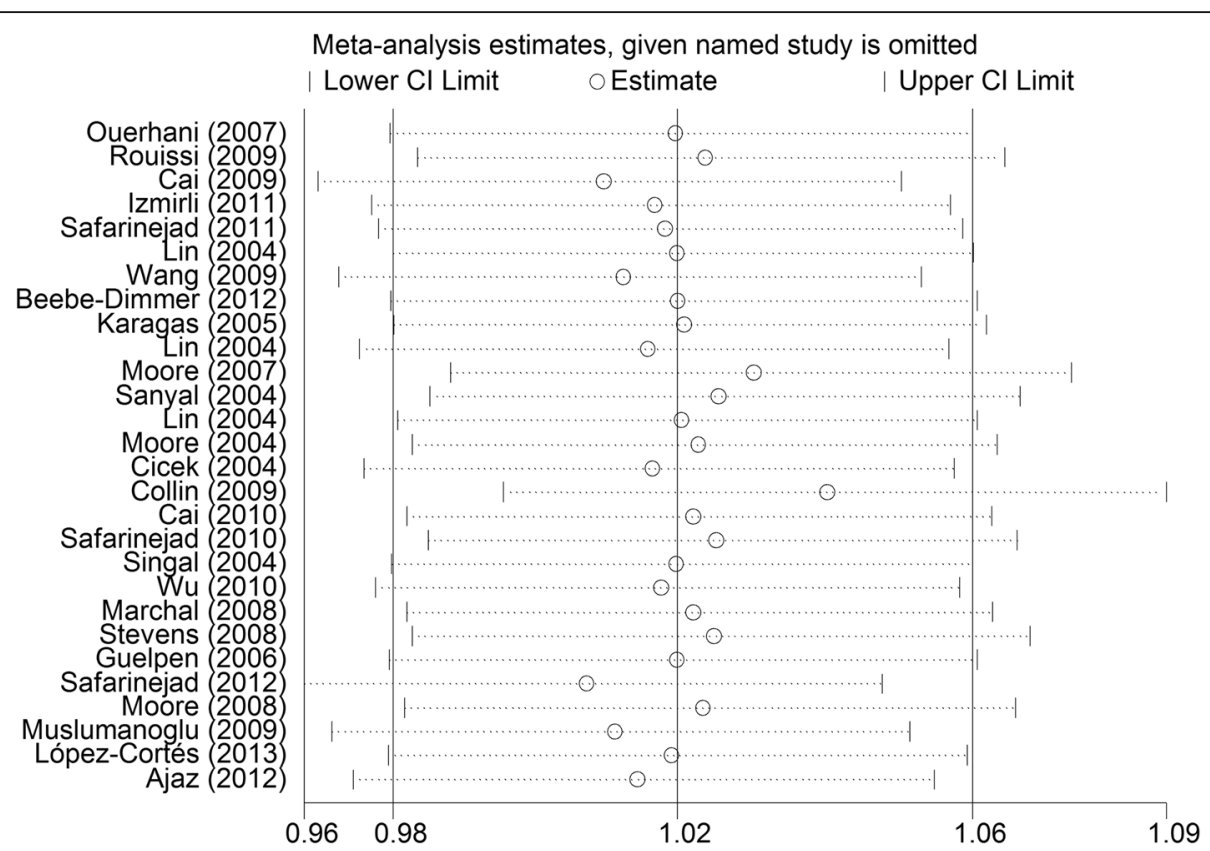

Fig. 11 Sensitivity analysis between the MTHFR rs1801131 polymorphism and whole urinary cancers' risk (C-allele vs. A-allele)

homocysteine levels and gastric cancer risk and were modulated by genotypes of MTHFR simultaneously [56]. Third, the rs3819102 polymorphism in TYMS might increase susceptibility to the risk of lung cancer [57]. Fourth, the SHMT1 C1420T polymorphism was associated with decreased risk of breast cancer [58]. Above information predicted one-carbon metabolism genes: MTHFR and others may influence different kinds of tumors' development, which maybe become intervention and treatment target genes in the future.

There are some limitations inherent in the included studies. First, despite inclusion of all the eligible studies, the resultant sample size is still not large enough; this situation may increase the likelihood of type I and type II errors. Second, we just searched articles from Pubmed, some other studies maybe omitted. Third, the cancer may not be depended entirely on a gene or one kind of polymorphism, because different results were found in rs1801131 polymorphism, and in different SNPs (such as rs1801133 polymorphism) in the same MTHFR gene in current analysis, further studies should be to identified more valuable and credible polymorphisms. Fourth, it is necessary to evaluate the roles of some special environmental factors (such as age, gender, the body-mass index, diet, alcohol consumption, smoking status) and lifestyles. Fifth, significant associations were detected in different genetic models in the same subgroup, this inconsistency may indicate the influence of type I error by the repetitive comparison.

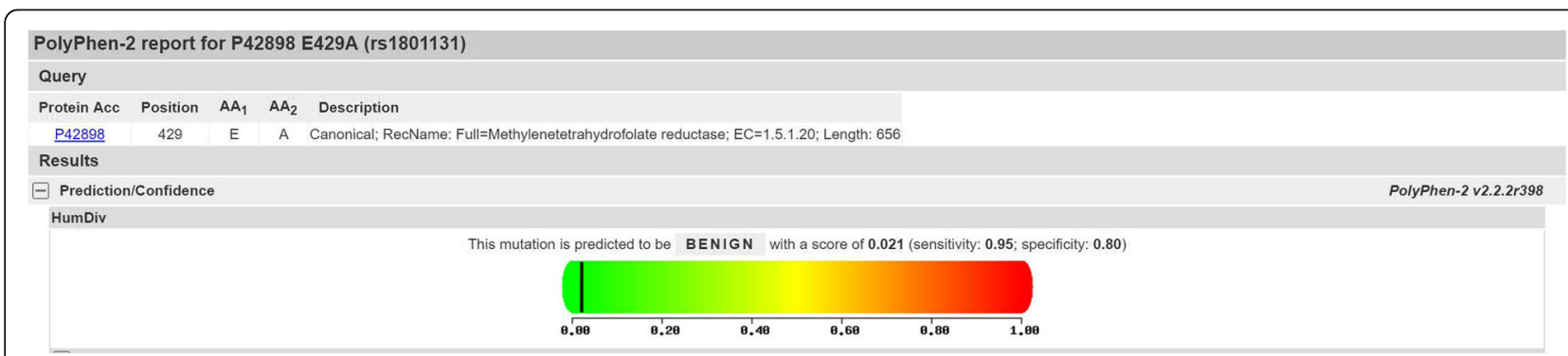

Fig. 12 Analysis of the effect of rs1801131 polymorphism on the MTHFR protein using the Polyphen-2 bioinformatics tool. The position of the black line represents the score, and a measure of how damaging the mutation could be as the protein function 


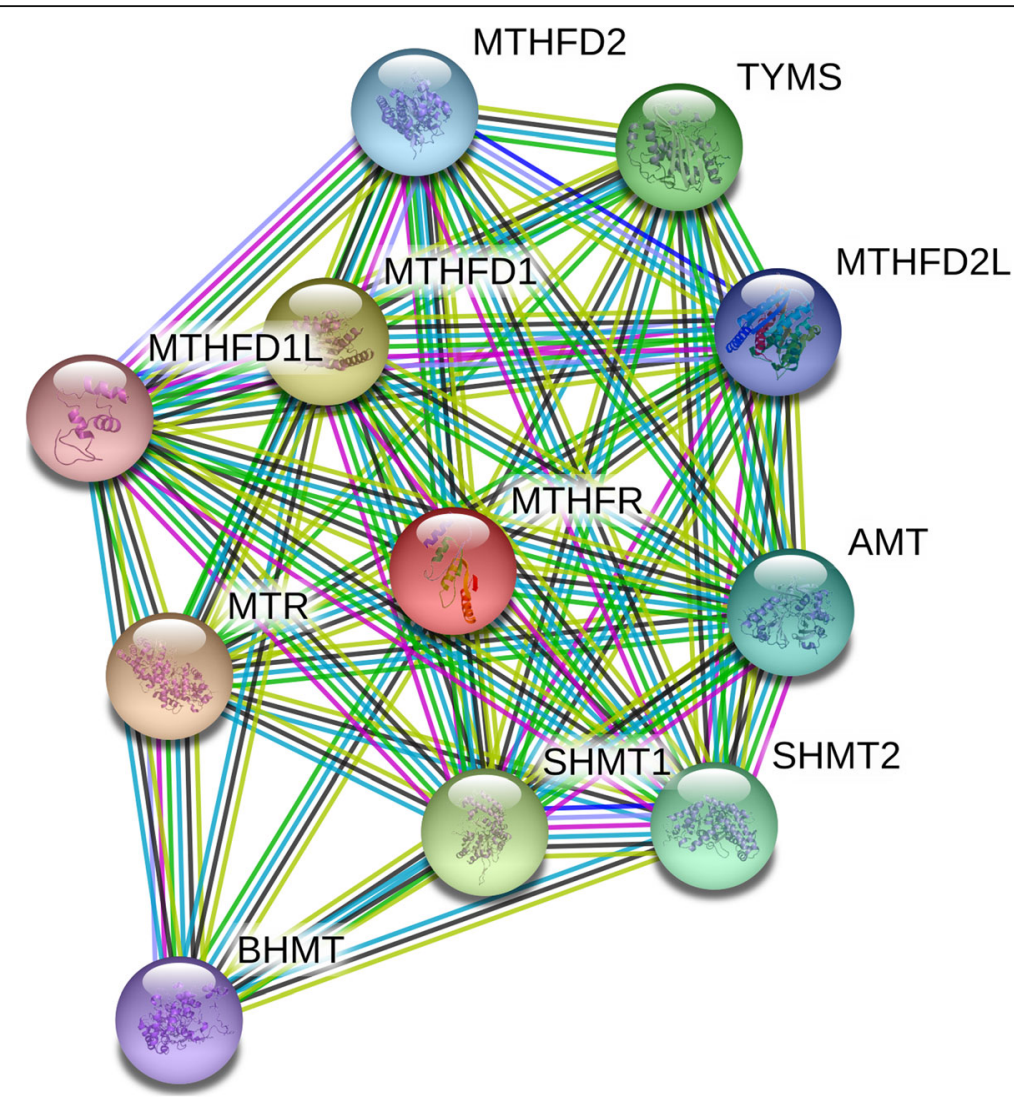

Fig. 13 Human MTHFR interactions network with other genes obtained from String server. At least 10 genes have been indicated to correlate with MTHFR gene. MTR: 5-methylterahydrofolate-homocysteine methyltransferase; MTHFD: Methylenetetrahydrofolate dehydrogenase (NADP+ dependent); SHMT1: Serine hydroxymethyltransferase 1(soluble); TYMS: Thymidylate synthetase; SHMT2: Serine hydroxymethyltransferase 2 (mitochondrial); AMT: Aminomethyltransferase; MTHFD2L: MTHFD 2-like (347 aa); BHMT: Betaine-homocysteine S-methyltransferase; MTHFD1L: MTHFD 1-like

In summary, our present update analysis suggested novel evidence that the MTHFR rs1801131 polymorphism has a risk effect for urinary cancers, especially bladder cancer. Further studies with larger samples, are needed to evaluate associations between MTHFR rs1801131 polymorphism and urinary cancers' risk.

\section{Abbreviations}

MTHFR: Methylenetetrahydrofolate reductase; 5,10-MTHF: 5,10methylenetetrahydrofolate; SAM: S-adenosylmethionine; ORs: Odds ratios; Cls: Confidence intervals; SNPs: Single nucleotide polymorphisms; HWE: Hardy-Weinberg equilibrium

\section{Acknowledgements}

Not applicable.

\section{Authors' contributions}

SX conceived the study. LZ searched the databases and extracted the data. LZ analyzed the data. SX wrote the draft of the paper. LZ reviewed the manuscript. The authors read and approved the final manuscript.

\section{Funding}

This work was supported by the High-Level Medical Talents Training Project of China (NO.2016CZBJ035).

\section{Availability of data and materials}

All the data generated in the present research is contained in this manuscript.

Ethics approval and consent to participate

Not applicable.

Consent for publication

Not applicable.

\section{Competing interests}

The authors declare that they have no competing interests.

\section{Author details}

'Department of Paediatrics, Changzhou No. 2 People's Hospital Affiliated to Nanjing Medical University, Changzhou 213003, Jiangsu Province, China. 2Department of Urology, Changzhou No. 2 People's Hospital Affiliated to Nanjing Medical University, Changzhou 213003, Jiangsu Province, China.

Received: 11 December 2019 Accepted: 14 April 2020 Published online: 27 April 2020

\section{References}

1. He H, Shui B. Folate intake and risk of bladder cancer: a meta-analysis of epidemiological studies. Int J Food Sci Nutr. 2014;65(3):286-92. 
2. Tio M, Andrici J, Cox MR, Eslick GD. Folate intake and the risk of prostate cancer: a systematic review and meta-analysis. Prostate Cancer Prostatic Dis. 2014;17(3):213-9.

3. Shen H, Newmann AS, Hu Z, Zhang Z, Xu Y, Wang L, Hu X, Guo J, Wang X, Wei Q. Methylenetetrahydrofolate reductase polymorphisms/haplotypes and risk of gastric cancer: a case-control analysis in China. Oncol Rep. 2005;13(2): 355-60

4. Wei Q, Shen H, Wang LE, Duphorne CM, Pillow PC, Guo Z, Qiao Y, Spitz MR. Association between low dietary folate intake and suboptimal cellular DNA repair capacity. Cancer Epidemiol Biomarkers Prev. 2003;12(10):963-9.

5. Friso S, Choi SW. Gene-nutrient interactions in one-carbon metabolism. Curr Drug Metab. 2005;6(1):37-46

6. Frosst P, Blom HJ, Milos R, Goyette P, Sheppard CA, Matthews RG, Boers GJ, den Heijer M, Kluijtmans LA, van den Heuvel LP, et al. A candidate genetic risk factor for vascular disease: a common mutation in methylenetetrahydrofolate reductase. Nat Genet. 1995;10(1):111-3.

7. Homberger A, Linnebank M, Winter C, Willenbring $H$, Marquardt $T$, Harms E, Koch HG. Genomic structure and transcript variants of the human methylenetetrahydrofolate reductase gene. Eur J Hum Genet. 2000;8(9):725-9.

8. van der Put NM, Gabreels F, Stevens EM, Smeitink JA, Trijbels FJ, Eskes TK, van den Heuvel LP, Blom HJ. A second common mutation in the methylenetetrahydrofolate reductase gene: an additional risk factor for neural-tube defects? Am J Hum Genet. 1998;62(5):1044-51.

9. Ajaz S, Khaliq S, Hashmi A, Naqvi SA, Rizvi SA, Mehdi SQ. Polymorphisms in the methylene tetrahydrofolate reductase gene and their unique combinations are associated with an increased susceptibility to the renal cancers. Genet Test Mol Biomarkers. 2012;16(5):346-52.

10. Beebe-Dimmer JL, lyer PT, Nriagu JO, Keele GR, Mehta S, Meliker JR, Lange EM, Schwartz AG, Zuhlke KA, Schottenfeld D, et al. Genetic variation in glutathione S-transferase omega-1, arsenic methyltransferase and methylene-tetrahydrofolate reductase, arsenic exposure and bladder cancer: a case-control study. Environ Health. 2012;11:43.

11. Cai D, Ning L, Pan C, Liu X, Bu R, Chen X, Wang K, Cheng Y, Wu B. Association of polymorphisms in folate metabolic genes and prostate cancer risk: a case-control study in a Chinese population. J Genet. 2010; 89(2):263-7.

12. Cai DW, Liu XF, Bu RG, Chen XN, Ning L, Cheng Y, Wu B. Genetic polymorphisms of MTHFR and aberrant promoter hypermethylation of the RASSF1A gene in bladder cancer risk in a Chinese population. J Int Med Res. 2009;37(6):1882-9.

13. Cicek MS, Nock NL, Li L, Conti DV, Casey G, Witte JS. Relationship between methylenetetrahydrofolate reductase C677T and A1298C genotypes and haplotypes and prostate cancer risk and aggressiveness. Cancer Epidemiol Biomarkers Prev. 2004;13(8):1331-6.

14. Collin SM, Metcalfe C, Zuccolo L, Lewis SJ, Chen L, Cox A, Davis M, Lane JA, Donovan J, Smith GD, et al. Association of folate-pathway gene polymorphisms with the risk of prostate cancer: a population-based nested case-control study, systematic review, and meta-analysis. Cancer Epidemiol Biomarkers Prev. 2009;18(9):2528-39.

15. Izmirli M, Inandiklioglu N, Abat D, Alptekin D, Demirhan O, Tansug Z, Bayazit Y. MTHFR gene polymorphisms in bladder cancer in the Turkish population. Asian Pac J Cancer Prev. 2011;12(7):1833-5.

16. Karagas MR, Park S, Nelson HH, Andrew AS, Mott L, Schned A, Kelsey KT. Methylenetetrahydrofolate reductase (MTHFR) variants and bladder cancer: a population-based case-control study. Int J Hyg Environ Health. 2005;208(5):321-7.

17. Lin J, Spitz MR, Wang Y, Schabath MB, Gorlov IP, Hernandez LM, Pillow PC, Grossman HB, Wu X. Polymorphisms of folate metabolic genes and susceptibility to bladder cancer: a case-control study. Carcinogenesis. 2004;25(9):1639-47.

18. Lopez-Cortes A, Jaramillo-Koupermann G, Munoz MJ, Cabrera A, Echeverria C, Rosales F, Vivar N, Paz-y-Mino C. Genetic polymorphisms in MTHFR (C677T, A1298C), MTR (A2756G) and MTRR (A66G) genes associated with pathological characteristics of prostate cancer in the Ecuadorian population. Am J Med Sci. 2013;346(6):447-54.

19. Marchal C, Redondo M, Reyes-Engel A, Perea-Milla E, Gaitan MJ, Machuca J, Diaz F, Caballero J, Carnero J. Association between polymorphisms of folate-metabolizing enzymes and risk of prostate cancer. Eur J Surg Oncol. 2008;34(7):805-10.

20. Moore LE, Hung R, Karami S, Boffetta P, Berndt S, Hsu CC, Zaridze D, Janout V, Kollarova H, Bencko V, et al. Folate metabolism genes, vegetable intake and renal cancer risk in Central Europe. Int J Cancer. 2008;122(8):1710-5.
21. Moore LE, Malats N, Rothman N, Real FX, Kogevinas M, Karami S, GarciaClosas R, Silverman D, Chanock S, Welch R, et al. Polymorphisms in onecarbon metabolism and trans-sulfuration pathway genes and susceptibility to bladder cancer. Int J Cancer. 2007;120(11):2452-8.

22. Moore LE, Wiencke JK, Bates MN, Zheng S, Rey OA, Smith AH. Investigation of genetic polymorphisms and smoking in a bladder cancer case-control study in Argentina. Cancer Lett. 2004;211(2):199-207.

23. Muslumanoglu MH, Tepeli E, Demir S, Uludag A, Uzun D, Atli E, Canturk KM, Ozdemir M, Turgut M. The analysis of the relationship between A1298C and C677T polymorphisms of the MTHFR gene with prostate cancer in Eskisehir population. Genet Test Mol Biomarkers. 2009;13(5):641-5.

24. Ouerhani S, Oliveira E, Marrakchi R, Ben Slama MR, Sfaxi M, Ayed M, Chebil M, Amorim A, El Gaaied AB, Prata MJ. Methylenetetrahydrofolate reductase and methionine synthase polymorphisms and risk of bladder cancer in a Tunisian population. Cancer Genet Cytogenet. 2007;176(1):48-53.

25. Rouissi K, Ouerhani S, Oliveira E, Marrakchi R, Cherni L, Ben Othman F, Ben Slama MR, Sfaxi M, Ayed M, Chebil M, et al. Polymorphisms in one-carbon metabolism pathway genes and risk for bladder cancer in a Tunisian population. Cancer Genet Cytogenet. 2009;195(1):43-53.

26. Safarinejad MR, Shafiei N, Safarinejad S. Relationship between three polymorphisms of methylenetetrahydrofolate reductase (MTHFR C677T, A1298C, and G1793A) gene and risk of prostate cancer: a case-control study. Prostate. 2010;70(15):1645-57.

27. Safarinejad MR, Shafiei N, Safarinejad S. Genetic susceptibility of methylenetetrahydrofolate reductase (MTHFR) gene C677T, A1298C, and G1793A polymorphisms with risk for bladder transitional cell carcinoma in men. Med Oncol. 2011;28(Suppl 1):S398-412.

28. Safarinejad MR, Shafiei N, Safarinejad S. Methylenetetrahydrofolate reductase (MTHFR) gene C677T, A1298C and G1793A polymorphisms: association with risk for clear cell renal cell carcinoma and tumour behaviour in men. Clin Oncol (R Coll Radiol). 2012;24(4):269-81.

29. Sanyal S, Festa F, Sakano S, Zhang Z, Steineck G, Norming U, Wijkstrom H, Larsson P, Kumar R, Hemminki K. Polymorphisms in DNA repair and metabolic genes in bladder cancer. Carcinogenesis. 2004;25(5):729-34.

30. Singal R, Ferdinand L, Das PM, Reis IM, Schlesselman JJ. Polymorphisms in the methylenetetrahydrofolate reductase gene and prostate cancer risk. Int J Oncol. 2004;25(5):1465-71.

31. Stevens VL, Rodriguez C, Sun J, Talbot JT, Thun MJ, Calle EE. No association of single nucleotide polymorphisms in one-carbon metabolism genes with prostate cancer risk. Cancer Epidemiol Biomarkers Prev. 2008;17(12):3612-4.

32. Van Guelpen BR, Wiren SM, Bergh AR, Hallmans G, Stattin PE, Hultdin J. Polymorphisms of methylenetetrahydrofolate reductase and the risk of prostate cancer: a nested case-control study. Eur J Cancer Prev. 2006;15(1): 46-50.

33. Wang M, Zhu H, Fu G, Wang M, Zhang Z, Lu Q, Wang S, Zhang Z. Polymorphisms of methylenetetrahydrofolate reductase and methionine synthase genes and bladder cancer risk: a case-control study with metaanalysis. Clin Exp Med. 2009;9(1):9-19.

34. Wu HC, Chang $\mathrm{CH}$, Tsai RY, Lin $\mathrm{CH}$, Wang RF, Tsai CW, Chen $\mathrm{KB}$, Yao CH, Chiu CF, Bau DT, et al. Significant association of methylenetetrahydrofolate reductase single nucleotide polymorphisms with prostate cancer susceptibility in Taiwan. Anticancer Res. 2010;30(9):3573-7.

35. Wells G, Shea B, O'Connell D, Robertson J, Peterson J, Welch V, Losos M, Tugwell P. The Newcastle-Ottawa Scale (NOS) for assessing the quality of nonrandomised studies in meta-analyses. Ottawa: Ottawa Health Research Institute; 2011.

36. Zintzaras E, loannidis JP. Heterogeneity testing in meta-analysis of genome searches. Genet Epidemiol. 2005:28(2):123-37.

37. Zintzaras E, Hadjigeorgiou GM. The role of G196A polymorphism in the brain-derived neurotrophic factor gene in the cause of Parkinson's disease: a meta-analysis. J Hum Genet. 2005;50(11):560-6.

38. Melsen WG, Bootsma MC, Rovers MM, Bonten MJ. The effects of clinical and statistical heterogeneity on the predictive values of results from metaanalyses. Clin Microbiol Infect. 2014;20(2):123-9.

39. Higgins JP, Thompson SG, Deeks JJ, Altman DG. Measuring inconsistency in meta-analyses. BMJ. 2003;327(7414):557-60.

40. Begg CB, Mazumdar M. Operating characteristics of a rank correlation test for publication bias. Biometrics. 1994;50(4):1088-101.

41. DerSimonian R, Laird N. Meta-analysis in clinical trials. Control Clin Trials. 1986;7(3):177-88.

42. Mantel N, Haenszel W. Statistical aspects of the analysis of data from retrospective studies of disease. J Natl Cancer Inst. 1959;22(4):719-48. 
43. Imani MM, Golchin N, Safaei M, Rezaei F, Abbasi H, Sadeghi M, Lopez-Jornet P, Mozaffari HR, Sharifi R. Methylenetetrahydrofolate reductase C677T polymorphism is not associated with the risk of nonsyndromic cleft lip/ palate: an updated meta-analysis. Sci Rep. 2020;10(1):1531.

44. Egger M, Davey Smith G, Schneider M, Minder C. Bias in meta-analysis detected by a simple, graphical test. BMJ. 1997;315(7109):629-34.

45. Hayashino Y, Noguchi Y, Fukui T. Systematic evaluation and comparison of statistical tests for publication bias. J Epidemiol. 2005;15(6):235-43.

46. Shao HB, Ren K, Gao SL, Zou JG, Mi YY, Zhang LF, Zuo L, Okada A, Yasui T. Human methionine synthase A2756G polymorphism increases susceptibility to prostate cancer. Aging. 2018;10(7):1776-88.

47. Liu X, Zhang Y, Gao X, Zhang L, Liu T, Jiang T. Association between methylenetetrahydrofolate reductase gene rs1801133 C/T polymorphism and urinary cancer risk. Int J Clin Exp Med. 2016;9(5):7743-53.

48. Zhu XL, Liu ZZ, Yan SX, Wang W, Chang RX, Zhang CY, Guo Y. Association between the MTHFR A1298C polymorphism and risk of cancer: evidence from 265 case-control studies. Mol Genet Genomics. 2016;291(1):51-63.

49. Pharoah PD, Dunning AM, Ponder BA, Easton DF. Association studies for finding cancer-susceptibility genetic variants. Nat Rev Cancer. 2004;4(11): 850-60.

50. Taflin H, Wettergren Y, Odin E, Carlsson G, Derwinger K. Folate levels and polymorphisms in the genes MTHFR, MTR, and TS in colorectal Cancer. Clin Med Insights Oncol. 2014;8:15-20

51. Yang D, Baumgartner RN, Slattery ML, Wang C, Giuliano AR, Murtaugh MA, Risendal BC, Byers T, Baumgartner KB. Dietary intake of folate, B-vitamins and methionine and breast cancer risk among Hispanic and non-Hispanic white women. PLoS One. 2013;8(2):e54495.

52. Yin G, Kono S, Toyomura K, Hagiwara T, Nagano J, Mizoue T, Mibu R, Tanaka M, Kakeji Y, Maehara Y, et al. Methylenetetrahydrofolate reductase C677T and A1298C polymorphisms and colorectal cancer: the Fukuoka colorectal Cancer study. Cancer Sci. 2004;95(11):908-13.

53. Liu H, Jin G, Wang H, Wu W, Liu Y, Qian J, Fan W, Ma H, Miao R, Hu Z, et al. Association of polymorphisms in one-carbon metabolizing genes and lung cancer risk: a case-control study in Chinese population. Lung Cancer. 2008; 61(1):21-9.

54. Jiang-Hua Q, De-Chuang J, Zhen-Duo L, Shu-de C, Zhenzhen L. Association of methylenetetrahydrofolate reductase and methionine synthase polymorphisms with breast cancer risk and interaction with folate, vitamin B6, and vitamin B 12 intakes. Tumour Biol. 2014;35(12):11895-901.

55. Weiner AS, Boyarskikh UA, Voronina EN, Selezneva IA, Sinkina TV, Lazarev AF, Petrova VD, Filipenko ML. Polymorphisms in the folate-metabolizing genes MTR, MTRR, and CBS and breast cancer risk. Cancer Epidemiol. 2012;36(2): e95-e100.

56. Wang L, Ke Q, Chen W, Wang J, Tan Y, Zhou Y, Hua Z, Ding W, Niu J, Shen J, et al. Polymorphisms of MTHFD, plasma homocysteine levels, and risk of gastric cancer in a high-risk Chinese population. Clin Cancer Res. 2007;13(8): 2526-32.

57. Feng W, Guo X, Huang H, Xu C, Li Y, Guo S, Zhao Z, Li Q, Lu D, Jin L, et al. Polymorphism rs3819102 in thymidylate synthase and environmental factors: effects on lung cancer in Chinese population. Curr Probl Cancer. 2018;43:66-74

58. Zhao TT, Shen LL, Zhang XL, Gu DY, Zhang Q, Huo XY, Tang CJ, Chen JF. Clinical significance of SHMT1 rs1979277 polymorphism in Asian solid tumors: evidence from a meta-analysis. Genet Mol Res. 2015;14(2):5602-14.

\section{Publisher's Note}

Springer Nature remains neutral with regard to jurisdictional claims in published maps and institutional affiliations.

Ready to submit your research? Choose BMC and benefit from:

- fast, convenient online submission

- thorough peer review by experienced researchers in your field

- rapid publication on acceptance

- support for research data, including large and complex data types

- gold Open Access which fosters wider collaboration and increased citations

- maximum visibility for your research: over $100 \mathrm{M}$ website views per year

At $\mathrm{BMC}$, research is always in progress.

Learn more biomedcentral.com/submissions 